\title{
Pengaruh Konsentrasi Aktivator Terhadap Kualitas Karbon Aktif dari Batubara Lignit
}

\author{
Arif Nurrahman $^{1 *}$, Edwin Permana ${ }^{2}$, Diah Riski Gusti ${ }^{3}$, Intan Lestari ${ }^{4}$ \\ ${ }^{1}$ Politeknik Energi dan Mineral Akamigas, Jalan Gajah Mada No. 38 Cepu, Blora, Jawa Tengah \\ ${ }^{2}$ Program Studi Kimia Industri, Fakultas Sains dan Teknologi, Universitas Jambi, Jambi, Indonesia, J1. Jambi-Ma. Bulian KM15 Mendalo Darat \\ Jambi 36361 \\ 3,4,Program Studi Kimia, Fakultas Sains dan Teknologi, Universitas Jambi, Jambi, Indonesia, J1. Jambi-Ma. Bulian KM15 Mendalo Darat Jambi \\ 36361 \\ *Email: anurrahman@esdm.go.id
}

\begin{abstract}
ABSTRAK
Karbon aktif sudah banyak digunakan dalam kehidupan sehari-hari. Salah satunya dalam penjernihan air. Bahan pembuatan karbon aktif telah dibuat dan diteliti. Batubara merupakan salah satu bahan yang dapat diolah menjadi karbon aktif. Ketersediaan batubara di Indonesia cukup melimpah dan berpotensi untuk dijadikan karbon aktif. Batubara yang digunakan yaitu jenis lignit. Batubara ini dikategorikan jenis batubara muda dimana penggunaannya hanya digunakan sebagai bahan bakar di industri. Diharapkan karbon aktif dari batubara ini menjadi sumber alternative penggunaan batubara di Indonesia. Karbon Aktif dari batubara ini menggunakan variable konsentrasi dari 0,5 M, 1 M, 1,5 M, 2 M, 2,5 M, 3 M dengan larutan activator HCL. Penelitian ini diharapkan hasilnya sesuai dengan standar kualitas SNI 06-3730-1995.
\end{abstract}

Kata Kunci: Aktivator, Batubara, Karbon Aktif, Konsentrasi

\begin{abstract}
Activated carbon has been widely used in everyday life. One of them is in water purification. Materials for making activated carbon have been made and researched. Coal is one of the materials that can be processed into activated carbon. The availability of coal in Indonesia is quite abundant and has the potential to be used as activated carbon. The coal used is lignite. This coal is categorized as light coal where its use is only used as fuel in industry. It is hoped that the activated carbon from this coal will become an alternative source of coal use in Indonesia. Activated carbon from coal uses a variable concentration of $0.5 \mathrm{M}, 1 \mathrm{M}, 1.5 \mathrm{M}, 2 \mathrm{M}, 2.5 \mathrm{M}, 3 \mathrm{M}$ with HCL activator solution. It is hoped that the results of this study are in accordance with the quality standard of SNI 06-3730-1995.
\end{abstract}

Key Words : Aktivator, Activated Carbon, Coal, Concentration.

\section{Pendahuluan}

Karbon aktif merupakan adsorben yang sangat dibutuhkan dalam proses industri, antara lain industri obatobatan, makanan, minuman, pengolahan air (penjernihan air), dan lain-lain (Rahim dan Indriyani, 2010). Karbon aktif dapat dibuat dari bahan yang mengandung karbon, baik dari tumbuh-tumbuhan, hewan, maupun barang tambang. Bahan dari tumbuhan yang cukup bagus dijadikan karbon aktif antara lain kulit singkong (Santoso dkk., 2014), bonggol jagung manis (Komariah dkk., 2013), tempurung kelapa (Pujiyanto, 2010; Pambayun dkk., 2013), biji salak (Turmuzi dan Syahputra, 2015), kulit jeruk (Erprihana dan Hartanto, 2014), dan pelepah aren (Esterlita dan Herlina, 2015). Karbon aktif juga dapat dibuat dari tanah gambut (Anjoko, dkk., 2014). Karbon aktif merupakan karbon dengan struktur amorphous atau mikrokristalin yang sebagian besar terdiri dari karbon bebas yang biasanya diperoleh dengan perlakuan khusus dan memiliki daya serap tinggi (Kusdarini dkk., 2017).

Salah satu bahan karbon aktif yang jumlahnya banyak adalah batubara. Batubara sebagai barang tambang sangat berpotensi untuk diolah menjadi karbon aktif dengan proses produksi yang lebih mudah dan ketersediaan bahan yang masih melimpah. Hal ini mengingat banyaknya cadangan batubara Indonesia terutama batubara peringkat rendah yang belum banyak dimanfaatkan. Batubara Merupakan salah satu kekayaan alam negara indonesia. Total sumber batubara di Indonesia diperkirakan mencapai 105 miliar per ton, dimana cadangan batubara diperkirakan 21 miliar ton (ESDM, 2011). Salah satu pulau di Indonesia yang memiliki potensi batubara terbanyak adalah Sumatera. Sumber daya batubara Sumatera saat ini mencapai 64.592,37 juta ton, dengan cadangan batubara sebesar 14.799,99 juta ton yang kualitasnya bervariasi, mulai dari batubara kalori tinggi sampai batubara kalori rendah (Anonim, 2011).

Berdasarkan kajian Tim Pusat Sumber Daya Geologi Tahun 2011, sekitar 30\% dari sumber daya batubara yang terdapat di Sumatera merupakan batubara kualitas rendah (lignit) dengan nilai kalori batubara di bawah $5.100 \mathrm{kal} / \mathrm{gr}$ (adb). Batubara kualitas rendah (lignit) ini tersebar hampir di seluruh daerah di Sumatera mulai dari Provinsi Nangroe Aceh Darusalam, Sumatera Utara, Riau (daratan), Jambi, Bengkulu, Sumatera Selatan dan Provinsi Lampung. Kadar fixed karbon yang cukup tinggi pada batubara lignit mendorong berkembangnya gagasan untuk memanfaatkan bahan ini menjadi karbon aktif. Melalui pemanfaatan batubara sebagai bahan baku karbon aktif diharapkan dapat meningkatkan pemanfaatan batubara Indonesia yang selama ini hanya digunakan sebagai bahan bakar PLTU, industri semen, dan industri-industri kecil lainnya.

Berdasarkan UU Pertambangan Mineral dan Batubara (Minerba) Nomor 4 Tahun 2009 pasal 102-103, pemilik IUP (Ijin Usaha Pertambangan) dan IUPK (Ijin Usaha Pertambangan Khusus) mempunyai kewajiban untuk meningkatkan nilai ekonomis batubara pada proses penambangan dan pengolahan. Berdasarkan nilai kalorinya dari yang paling besar ke yang paling kecil, batubara Indonesia termasuk ke dalam jenis antrasit, bituminus, sub bituminus, dan lignit (brown coal). Batubara dapat dimanfaatkan dalam 3 jenis, yaitu sebagai bahan bakar langsung, bahan bakar tidak langsung, serta sebagai non bahan bakar (Ghafarunnisa dkk., 2017). 
Usaha pemanfaatan batu bara sebagai bahan karbon aktif telah dilakukan beberapa peneliti. Penelitian pembuatan karbon aktif dari batubara jenis lignit dengan reagen $\mathrm{NaOH}$ 5\% berat menghasilkan karbon aktif yang sudah memenuhi standar SNI 06-3730-1995 untuk kadar air, bagian yang hilang pada pemanasan $950^{\circ} \mathrm{C}$, dan daya serap iod (Rahim dan Indriyani, 2010). Kelemahan penelitian ini adalah kadar abu belum memenuhi standar SNI 06-3730-1995.

Selain penggunaan batubara sebagai bahan baku karbon aktif dilaporkan juga penggunaaan aktivator yang berbeda. Menurut Kirk and Othmer (1940), bahan kimia yang dapat digunakan sebagai pengaktif diantaranya $\mathrm{CaCl} 2, \mathrm{Ca}(\mathrm{OH}) 2$, $\mathrm{NaCl}, \mathrm{MgCl}$, HNO3, HCl, Ca3(PO4)2, H3PO4, ZnCl2, dan sebagainya. Penggunaan reagen $\mathrm{H} 3 \mathrm{PO} 4$ dilaporkan merupakan aktivator yang terbaik untuk mengaktivasi pelepah aren dibandingkan $\mathrm{ZnCl} 2$ dan $\mathrm{KOH}$ (Esterlita dan Herlina, 2015).

Sejak lama, batubara telah digunakan sebagai bahan baku pembuatan karbon aktif. Meskipun demikian, penelitian yang berkaitan dengan penggunaan batubara Indonesia sebagai bahan baku karbon aktif tetap perlu dilakukan terutama untuk memperoleh kondisi operasi yang memberikan perolehan dan kualitas yang maksimum. Pembuatan karbon aktif dari batubara Indonesia akan mendorong pemanfaatan batubara yang saat ini dirasakan masih terbatas. Pembuatan karbon aktif dilakukan dengan proses karbonisasi yang dilanjutkan dengan proses aktivasi. Aktivasi adalah proses perlakuan terhadap karbon untuk membuka pori karbon. Proses aktivasi dapat dilakukan melalui aktivasi secara fisika dan aktivasi secara kimia (Ghafarunnisa dkk., 2017).

Pada penelitian ini akan digunakan batubara jenis lignit untuk pembuatan karbon aktif dengan proses karbonisasi dan aktivasi kimia menggunakan aktivator asam klorida $(\mathrm{HCl})$. Hasil penelitian diharapkan dapat mengetahui kualitas karbon aktif dari batubara jenis lignit dengan proses karbonisasi dan aktivasi kimia menggunakan aktivator asam klorida $(\mathrm{HCl})$ menurut SNI 06-3730-1995, Mengetahui pengaruh konsentrasi aktivator asam klorida $(\mathrm{HCl})$ terhadap kualitas karbon aktif yang memenuhi Standar Nasional Indonesia SNI 06-37301995 dan Mengetahui karakterisasi FTIR, XRD dan SEM karbon aktif dari batubara jenis lignit dengan proses karbonisasi dan aktivasi kimia menggunakan aktivator asam klorida $(\mathrm{HCl})$

\section{Metodologi Penelitian}

\subsection{Alat dan Bahan}

Peralatan yang digunakan pada penelitian ini adalah Ayakan, Timbangan digital, magnetic stirer. Sedangkan untuk uji karakterisasi menggunakan instument FTIR, XRD dan SEM. Adapun bahan-bahan yang digunakan pada penelitian ini adalah Batubara jenis lignit, Asam Kloida ( $\mathrm{HCl})$ Teknis $32 \%$, Natrium tiosulfat pentahidrat (Na2S2O3.5H2O) $0,1 \mathrm{~N}$, Larutan iodin 0,1 N, Amilum 1\%, Aquades

\subsection{Prosedur Kerja \\ Preparasi Sampel}

Sebelum dibuat arang aktif, batubara dimasukan ke dalam crusher untuk di perkecil ukurannyadigiling dan selanjutnya disaring dengan ayakan 100 mesh. Selanjutnya sampel di masukan ke dalam furnace atau tungku untuk proses karbonisasi pada suhu 700 oC selama 3 jam. Setelah proses pendinginan, sampel dimasukan ke dalam crusher lagi untuk diperhalus ukurannya dan selanjutnya disaring dengan ayakan 100 mesh. Setelah itu kemudian masuk ke proses aktivasi (Kusdarini, dkk, 2016).

\section{Proses Aktivasi Karbon Aktif}

Aktivasi karbon aktif berarti menghilangkan zat-zat yang menutupi pori-pori pada permukaan arang dan memperluas poripori arang. Dimana dalam penelitian ini digunakan pengaktivasi asam klorida $(\mathrm{HCl})$. Karbon aktif sebanyak 60 gram diaktivasi di dalam larutan aktivator $\mathrm{HCl}$ sebanyak 200 ml dengan masing-masing konsentrasi $0,5 \mathrm{M}, 1 \mathrm{M}, 1,5 \mathrm{M}, 2$ M, 2,5 M dan 3 M dengan waktu 24 jam. Sampel kemudian disaring, dan dicuci dengan aquadest hingga $\mathrm{pH}$ 7. Sampel dikeringkan dalam oven dari suhu kamar sampai suhu $110 \mathrm{oC}$ selama 2 jam. Karbon aktif yang telah diaktivasi kemudian dilakukan pengujian kualitas agar diperoleh arang aktif yang memenuhi persyaratan menurut Standar Nasional Indonesia (SNI 06-3730-1995).

\section{Pengujian Kualitas Karbon Aktif}

Untuk analisa data, dilakukan pengujian kualitas karbon aktif yang telah di aktivasi agar diperoleh arang aktif yang memenuhi persyaratan menurut Standar Nasional Indonesia (SNI 06-3730-1995) dengan melakukan pengujian kadar air, kadar abu, kadar zat menguap, kadar karbon terikat dan daya serap iodin. Untuk mengetahui pola struktur arang aktif dilakukan analisis menggunakan: Fourier transform infra red (FTIR) digunakan untuk mengetahui perubahan gugus fungsi. X-ray diffraction (XRD) untuk mengetahui derajat kristalinitas, tinggi, lebar, jarak, dan jumlah lapisan aromatik. Sedangkan untuk mengetahui morfologi permukaan karbon aktif maka dilakukan analisis dengan menggunakan SEM.

\section{Pengujian Kadar Air}

Karbon aktif ditimbang seberat 1 gram dan dimasukkan ke dalam kurs porselin yang telah dikeringkan, setelah itu dimasukkan ke dalam oven pada suhu $105^{\circ} \mathrm{C}$ selama 1 jam, kemudian karbon aktif didinginkan dalam desikator dan di timbang. Kadar air dapat dihitung dengan persamaan berikut:

$$
\text { Kadar Air }=\frac{W 2-W 3}{W 2-W 1} \times 100 \%
$$

Dimana: $\mathrm{W} 1$ = Massa cawan kosong $\mathrm{W} 2$ = Massa cawan + sampel awal W3 = Massa cawan + sampel akhir

\section{Pengujian Kadar Abu}

Karbon aktif ditimbang seberat 1 gram dan dimasukkan ke dalam kurs porselin yang telah dikeringkan, setelah itu dimasukkan ke dalam furnace pada suhu $650^{\circ} \mathrm{C}$ selama 3 jam, kemudian karbon aktif didinginkan dalam desikator dan di timbang. Kadar air dapat dihitung dengan persamaan berikut:

$$
\text { Kadar Abu }=\frac{W 3-W 1}{W 2-W 1} \times 100 \%
$$

Dimana: W1 = Massa cawan kosong

$$
\begin{aligned}
& \text { W2 }=\text { Massa cawan + sampel awal } \\
& \text { W3 }=\text { Massa cawan + sampel akhir }
\end{aligned}
$$

\section{Pengujian Kadar Zat Menguap/Zat Terbang}

Sebanyak 1 gram sampel ditimbang dalam cawan porselen yang telah diketahui bobot keringnya. Cawan kemudian dipanaskan dalam furnace pada suhu $750^{\circ} \mathrm{C}$ selama 7 menit, 
kemudian didinginkan dalam desikator, dan ditimbang. Cawan ditutup serapat mungkin. Kadar zat terbang dihitung berdasarkan persamaan:

$$
\text { Kadar Zat Terbang }=\frac{W 2-W 3}{W 2-W 1} \times 100 \%
$$

Dimana: Massa cawan kosong (W1)

Massa cawan + sampel awal (W2)

Massa cawan + sampel akhir (W3)

\section{Pengujian Kadar Karbon Terikat}

Karbon dalam arang aktif adalah hasil dari proses pengarangan/karbonisasi selain abu (zat anorganik) dan zat terbang (zat-zat atsiri yang masih terdapat pada pori pori arang). Definisi ini hanya berupa pendekatan (SNI 1995). Pengukuran kadar karbon terikat dihitung dengan menggunakan rumus:

Kadar Karbon Terikat $(\%)=100 \%$ - $($ Kadar Zat Menguap + Kadar Abu) $\%$

\section{Pengujian Daya Serap Iodin}

Pengujian daya serap iodin merupakan faktor utama untuk menentukan arang aktif terbaik yang akan digunakan sebagai adsorben pada penelitian selanjutnya.

Sampel kering sebanyak $\pm 0,25 \mathrm{~g}$ dimasukkan kedalam labu erlenmeyer yang dibungkus aluminium foil, ditambahkan $25 \mathrm{ml}$ larutan Iodin 0,1 N, kemudian dikocok selama 15 menit pada suhu kamar lalu disaring. Filtrat sebanyak $10 \mathrm{ml}$ dititrasi dengan larutan $\mathrm{Na}_{2} \mathrm{~S}_{2} \mathrm{O}_{3} .5 \mathrm{H}_{2} \mathrm{O} 0,1 \mathrm{~N}$ hingga berwarna kuning muda lalu diberi beberapa tetes indikator amilum $1 \%$ dan titrasi dilanjutkan sampai warna biru tepat hilang. Daya serap iodin dapat di hitung dengan persamaan di bawah ini:

Daya Serap Iodin $(\mathrm{mg} / \mathrm{g})=\frac{a}{b} \times \frac{(\text { Vblanko-Vsampel }) \times \mathrm{N} \times \mathrm{BE} \text { iod }}{\mathrm{W}}$ (5)

Keterangan:

$\mathrm{a}=$ Volume larutan iod untuk sampel $(\mathrm{ml})$

$\mathrm{b}=$ Volume filtrat $(\mathrm{ml})$

$\mathrm{V}=$ Volume $\mathrm{Na}_{2} \mathrm{~S}_{2} \mathrm{O}_{3}(\mathrm{ml})$

$\mathrm{N}=$ Normalitas $\mathrm{Na}_{2} \mathrm{~S}_{2} \mathrm{O}_{3}$

$\mathrm{BE}$ iod $=$ Berat ekuivalen iod

$\mathrm{W}=$ Berat karbon aktif (gram)

\section{Hasil dan Pembahasan}

\subsection{Pre-treatment Bahan Baku}

Bahan baku yang digunakan pada penelitian ini adalah batubara jenis lignit yang didapatkan dari Batanghari, Jambi. Sebelum batubara dilakukan proses pengarangan (karbonisasi), batubara dijemur terlebih dahulu dibawah sinar matahari untuk mengurangi kadar airnya. Dikarenakan batubara jenis ini memiliki kandungan airnya cukup tinggi.

\subsection{Proses Pembuatan Karbon Aktif Batubara}

Pada penelitian ini pembuatan karbon aktif melalui tiga proses tahapan yang berkelanjutan yaitu pemilihan bahan dasar, proses karbonisasi (pengarangan) dan proses aktivasi. Bahan dasar pembuatan karbon aktif pada penelitan ini adalah batubara jenis lignit, dikarenakan batubara termasuk bahan yang mengandung unsur karbon.

\subsection{Proses Pengarangan (Karbonisasi) Batubara}

Batubara yang telah dikeringkan dengan cara dijemur dibawah sinar matahari, batubara di hancurkan terlebih dahulu untuk memperkecil ukurannya sebelum dilakukan proses karbonisasi. Setelah ukuran batubara menjadi kecil lalu dimasukan ke dalam cawan untuk dilakukan proses karbonisasi. Alat yang digunakan pada proses karbonisasi ini adalah furnace (tanur). Dimana pada penelitian ini temperatur yang digunakan adalah 700oC dengan waktu selama 3 jam.

Setelah proses karbonisasi, batubara di dinginkan terlebih dahulu di dalam desikator. Setelah dingin, selanjutnya batubara dihancurkan kembali di dalam crusher untuk mendapatkan ukuran yang lebih kecil. Setelah itu batubara yang sudah di hancurkan di ayak untuk mendapatkan ukuran yang di inginkan dengan menggunakan ayakan 100 mesh. Dan didapatkan sampel batubara yang berukuran 100 mesh yang nantinya akan di aktivasi pada proses selanjutnya.

\subsection{Proses Aktivasi Karbon Aktif}

Proses aktivasi ini terdapat dua metode yang umum digunakan yaitu aktivasi fisika dan aktivasi kimia. Pada penelitian ini metode yang digunakan adalah aktivasi kimia dengan menggunakan aktivator asam klorida $(\mathrm{HCl})$. Arang batubara hasil dari proses karbonisasi yang sudah berukuran 100 mesh selanjutnya di aktivasi dengan cara perendaman arang batubara di dalam larutan asam klorida $(\mathrm{HCl})$. Preparasi diawali dengan menyiapkan larutan asam klorida $(\mathrm{HCl})$ dengan enam konsentrasi yang berbeda yaitu $0,5 \mathrm{M}, 1 \mathrm{M}, 1,5$ M, 2 M, 2,5 M dan 3 M. Kemudian arang batubara dimasukan kedalam masing-masing konsentrasi larutan aktivator tersebut. Waktu perendaman arang batubara pada larutan aktivator tersebut adalah 24 jam.

Setelah dilakukan perendaman selama 24 jam, langkah selanjutnya adalah penyaringan karbon aktif tersebut. Kemudian dilakukan pencucian karbon aktif tersebut dengan menggunakan aquades hingga pH 7 (netral). Setelah netral, karbon aktif tersebut di keringkan menggunakan oven dengan suhu $110^{\circ} \mathrm{C}$ selama 2 jam.

\section{Uji Kualitas Karbon Aktif dari Batubara}

Pada penelitian ini perlu dilakukan pengujian kualitas karbon aktif yang telah di aktivasi agar diperoleh karbon aktif yang memenuhi persyaratan menurut Standar Nasional Indonesia (SNI 06-3730-1995). Pengujian ini diantaranya meliputi pengujian kadar air, kadar abu, kadar zat menguap, kadar karbon terikat dan daya serap iodin.

\section{Uji Kadar Air}

Pengujian kadar air merupakan salah satu parameter yang harus di uji untuk mengetahui kualitas dari karbon aktif. Pengujian kadar air bertujuan untuk mengetahui kandungan air yang ada pada karbon aktif, agar sesuai dengan kualitas standar karbon aktif, yakni kandungan air maksimal $15 \%$. Untuk pengujian kadar air, karbon aktif di timbang seberat 1,20 gram dan dimasukkan ke dalam cawan yang telah dikeringkan. setelah itu kemudian dimasukkan ke dalam oven pada suhu $105^{\circ} \mathrm{C}$ selama 1 jam. Selanjutnya karbon aktif didinginkan dalam desikator dan di timbang 
Tabel 1. Data Hasil Pengamatan Analisa Kadar Air

\begin{tabular}{ccccc}
\hline $\begin{array}{c}\text { Konsentrasi } \\
\text { Aktivator }(\mathbf{M})\end{array}$ & $\begin{array}{c}\text { Massa Cawan } \\
\left.\text { Kosong }\left(\mathbf{W}_{\mathbf{1}}\right) \mathbf{( g r}\right)\end{array}$ & $\begin{array}{c}\text { Massa Cawan+Sampel } \\
\left.\text { Awal }\left(\mathbf{W}_{\mathbf{2}}\right) \mathbf{( g r}\right)\end{array}$ & $\begin{array}{c}\text { Massa Cawan+Sampel } \\
\text { Akhir }\left(\mathbf{W}_{\mathbf{3}}\right)(\mathbf{g r})\end{array}$ & $\begin{array}{c}\text { Kadar Air } \\
(\boldsymbol{\%})\end{array}$ \\
\hline 0,5 & 87,62 & 88,82 & 88,71 & 9,16 \\
1 & 84,77 & 85,97 & 85,86 & 9,16 \\
1,5 & 67,02 & 68,22 & 68,12 & 8,33 \\
2 & 46,16 & 47,36 & 47,27 & 7,5 \\
2,5 & 44,86 & 46,06 & 45,98 & 6,66 \\
3 & 80,13 & 81,33 & 81,26 & 5,83 \\
\hline
\end{tabular}

Menurut persyaratan kualitas karbon aktif Standar Nasional Indonesia (SNI) 06-3730-1995, kadar air maksimal yang terkandung dalam karbon aktif yang baik adalah $15 \%$. Berdasarkan tabel 4.1 dapat dilihat bahwa hasil analisa kadar air yang di peroleh berkisar antara 5,8 - 9,1\%. Maka hasil analisa kadar air pada penelitan ini telah memenuhi Standar Nasional Indonesia (SNI) 06-3730-1995, yakni kurang dari 15\%. Kadar air tertinggi dimiliki oleh karbon aktif yang diaktivasi dengan asam klorida $(\mathrm{HCl})$ pada konsentrasi $0,5 \mathrm{M}$ dan $1 \mathrm{M}$ dengan suhu karbonisasi $700^{\circ} \mathrm{C}$ yakni sebesar $9,1 \% 6$. Sedangkan untuk kadar air terendah dimiliki oleh karbon aktif yang diaktivasi dengan asam klorida $(\mathrm{HCl})$ pada konsentrasi 3 $\mathrm{M}$ dengan suhu karbonisasi $700^{\circ} \mathrm{C}$ yakni sebesar $5,83 \%$.

Kadar air pada karbon aktif merupakan persentase kandungan air karbon aktif yang dapat dinyatakan berdasarkan berat basah atau berdasarkan berat kering. Kadar air berat basah mempunyai batas maksimum teoritis sebesar $100 \%$. Kadar air berat basah atau berat kering dapat ditentukan dari bahan yang telah dikeringkan tersebut. Besarnya rasio pengeringan dapat dihitung dengan berat bahan sebelum pengeringan per berat setelah pengeringan (Winarno, 1991). Berdasarkan tabel 4.1 hasil analisa kadar air karbon aktif dapat diambil hubungan antara \% kadar air dengan konsentrasi $\mathrm{HCl}$ yang disajikan pada gambar 1

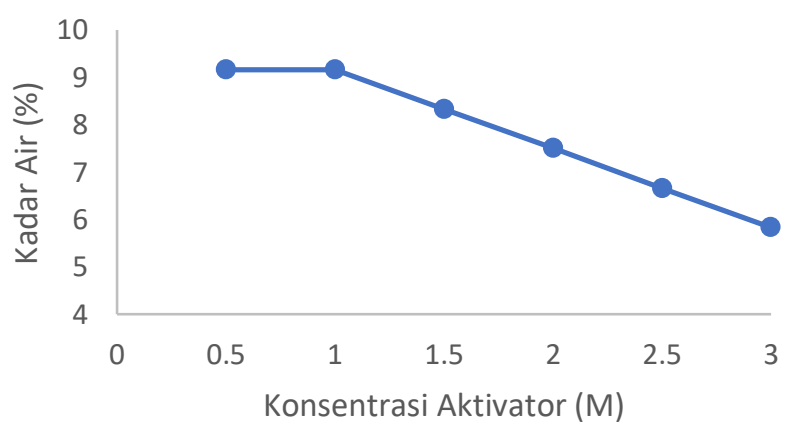
Gambar 1. Grafik Persentase Pengaruh Konsentrasi HCl
Terhadap Kadar Air

Dari diagram persentase pada gambar 1 terlihat bahwa persentase kadar air mengalami penurunan seiring dengan naiknya konsentrasi asam klorida $(\mathrm{HCl})$. Hal ini dapat disimpulkan bahwa semakin besar konsentrasi aktivator maka kadar air dalam karbon aktif semakin berkurang. Konsentrasi aktivator yang semakin besar mempengaruhi luas permukaan pori-pori, semakin luas permukaan maka akan meningkatkan penyerapan (adsorpsi) terhadap kandungan air. Suhu pada proses karbonisasi karbon aktif sebesar $700^{\circ} \mathrm{C}$. Penurunan kadar air disebabkan oleh terikatnya molekul air yang ada pada karbon aktif oleh aktivator yang menyebabkan pori-pori pada karbon aktif semakin besar. Semakin besar pori maka luas permukaan karbon aktif semakin bertambah. Jadi, semakin tinggi konsentrasi aktivator maka daya serap yang dihasilkan meningkat (Meilianti, 2017).

Hal ini sesuai dengan penelitian sebelumnya yang menyatakan bahwa penurunan kadar air sangat erat hubungannya dengan temperatur dan konsentrasi aktivator, dengan meningkatnya konsentrasi aktivator maka pori-pori akan semakin luas sehingga luas permukaan semakin bertambah, dan meningkatnya kemampuan adsorpsi dari karbon aktif (Masturi, dkk 2016). Kadar air diasumsikan bahwa hanya air yang merupakan senyawa volatil, karena dimungkinkan masih adanya air yang terjebak dalam rongga dan menutupi pori karbon aktif. Semakin rendah kadar air menunjukkan sedikitnya air yang tertinggal dan menutupi pori karbon aktif. Jika kadar air rendah maka banyak tempat di dalam pori yang dapat ditempati oleh molekul iodium (Ghafarunnisa, dkk 2017).

\section{Uji Kadar Abu}

Pengujian kadar abu merupakan salah satu parameter yang harus di uji untuk mengetahui kualitas dari karbon aktif. Kadar abu adalah campuran dari komponen anorganik atau mineral yang terdapat pada suatu bahan (Siregar MM, 2011). Pengujian kadar abu ini bertujuan untuk mengatahui kandungan abu pada karbon aktif dikarenakan apabila kandungan abu semakin tinggi maka mengakibatkan daya serap yang dihasilkan semakin rendah, karena itu diupayakan kandungan abu sekecil mungkin supaya proses adsorpsi yang terjadi dapat maksimal. Untuk pengujian kadar abu, karbon aktif ditimbang seberat 1,20 gram dan dimasukkan ke dalam cawan yang telah dikeringkan, setelah itu dimasukkan ke dalam furnace pada suhu $650^{\circ} \mathrm{C}$ selama 3 jam, kemudian karbon aktif didinginkan dalam desikator dan di timbang

Tabel 2. Data Hasil Pengamatan Analisa Kadar Abu

\begin{tabular}{ccccc}
\hline $\begin{array}{c}\text { Konsentrasi } \\
\text { Aktivator }(\mathbf{M})\end{array}$ & $\begin{array}{c}\text { Massa Cawan Kosong } \\
\left(\mathbf{W}_{\mathbf{1}}\right)(\mathbf{g r})\end{array}$ & $\begin{array}{c}\text { Massa Cawan+Sampel } \\
\text { Awal }\left(\mathbf{W}_{\mathbf{2}}\right)(\mathbf{g r})\end{array}$ & $\begin{array}{c}\text { Massa Cawan+Sampel } \\
\text { Akhir }\left(\mathbf{W}_{\mathbf{3}}\right)(\mathbf{g r})\end{array}$ & $\begin{array}{c}\text { Kadar Abu } \\
(\boldsymbol{\%})\end{array}$ \\
\hline 0,5 & 56,10 & 57,30 & 56,20 & 8,33 \\
1 & 58,15 & 59,35 & 58,24 & 7,5 \\
1,5 & 61,59 & 62,79 & 61,68 & 7,5 \\
2 & 58,84 & 60,04 & 58,92 & 6,66 \\
2,5 & 56,67 & 57,87 & 56,76 & 7,5 \\
3 & 53,53 & 54,73 & 53,61 & 6,66 \\
\hline
\end{tabular}


Menurut persyaratan kualitas karbon aktif Standar Nasional Indonesia (SNI) 06-3730-1995, kadar abu maksimal yang terkandung dalam karbon aktif yang baik adalah $10 \%$. Berdasarkan tabel 4.2 dapat dilihat bahwa hasil analisa kadar abu yang di peroleh berkisar antara 6,66 - 8,33\%. Maka hasil analisa kadar abu pada penelitan ini telah memenuhi Standar Nasional Indonesia (SNI) 06-3730-1995, yakni kurang dari $10 \%$.

Kadar abu pada karbon aktif merupakan persentase kandungan abu yang terdapat pada karbon aktif. Kadar abu sebagai sisa mineral yang tertinggal pada saat dibakar, karena bahan alam sebagai bahan dasar pembuatan karbon aktif tidak hanya mengandung senyawa karbon tetapi juga mengandung beberapa mineral, dimana sebagian dari mineral ini telah hilang pada saat karbonisasi dan aktivasi, sebagian lagi diperkirakan masih tertinggal dalam karbon aktif. Kandungan abu sangat berpengaruh pada kualitas karbon aktif. Keberadaan abu yang berlebihan dapat menyebabkan terjadinya penyumbatan pori-pori sehingga luas pemukaan karbon aktif menjadi berkurang (Yola, 2013). Berdasarkan tabel 4.2 hasil analisa kadar abu karbon aktif dapat diambil hubungan antara \% kadar abu dengan konsentrasi $\mathrm{HCl}$ yang disajikan pada gambar 2 .

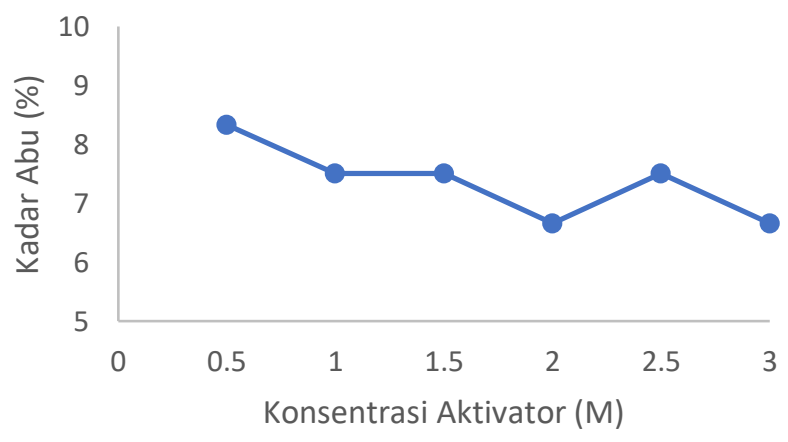

Gambar 2. Grafik Pengaruh Konsentrasi HCl Terhadap Kadar $\mathrm{Abu}$
Dari gambar 2, menunjukkan bahwa konsentrasi bahan aktivator tidak menyebabkan kenaikan kadar abu atau sebaliknya, tetapi menghasilkan karbon aktif dengan nilai kadar abu yang fluktuatif. Kadar abu merupakan sisa dari pembakaran yang sudah tidak memiliki unsur karbon dan nilai kalor lagi. Nilai kadar abu menunjukkan jumlah sisa dari akhir proses pembakaran berupa zat - zat mineral yang tidak hilang selama proses pembakaran. Hal ini dapat di simpulkan bahwa konsentrasi dan jenis aktivator tidak begitu mempengaruhi kadar abu.

Kandungan abu dapat menyumbat pori-pori karbon aktif. Keberadaan abu yang berlebihan dapat menyebabkan terjadinya penyumbatan pori-pori karbon aktif sehingga luas permukaan karbon aktif menjadi berkurang (Eliabeth, 2006). Peningkatan kadar abu terjadi karena terbentuknya garamgaram mineral pada saat proses pengarangan yang bila proses tersebut berlanjut akan membentuk partikel-partikel halus dari garam-garam mineral tersebut. Kadar abu juga dipengaruhi oleh besarnya kadar silikat, semakin besar kadar silikat maka kadar abu yang dihasilkan akan semakin besar (Pari 1996). Hasil penelitian kadar abu ini lebih rendah dibandingkan kadar abu karbon aktif yang diaktivasi dengan larutan $\mathrm{NaOH}$, yaitu 16,76 sampai 20,10\% (Rahim dan Indriyani, 2010).

\section{Uji Kadar Zat Terbang}

Pengujian kadar zat terbang merupakan salah satu parameter yang harus di uji untuk mengetahui kualitas dari karbon aktif. Pengujian kadar zat terbang ini bertujuan untuk mengetahui banyaknya zat yang menguap dari karon aktif, agar sesuai dengan kualitas standar karbon aktif, yakni kandungan zat terbang maksimal $25 \%$. Untuk pengujian kadar air, karbon aktif ditimbang seberat 1,20 gram dan dimasukkan ke dalam cawan yang telah dikeringkan, setelah itu dimasukkan ke dalam furnace pada suhu $750^{\circ} \mathrm{C}$ selama 7 menit, kemudian karbon aktif didinginkan dalam desikator dan di timbang. Cawan ditutup serapat mungkin. Data hasil uji kadar zat terbang dapat dilihat pada tabel 3.

Tabel 3. Data Hasil Pengamatan Analisa Kadar Zat Terbang

\begin{tabular}{|c|c|c|c|c|}
\hline $\begin{array}{c}\text { Konsentrasi } \\
\text { Aktivator (M) }\end{array}$ & $\begin{array}{c}\text { Massa Cawan } \\
\text { Kosong } \\
\left(W_{1}\right) \\
(\text { gr })\end{array}$ & $\begin{array}{c}\text { Massa } \\
\text { Cawan+Sampel } \\
\text { Awal }\left(\mathbf{W}_{2}\right) \\
(\mathrm{gr})\end{array}$ & $\begin{array}{c}\text { Massa } \\
\text { Cawan+Sampel } \\
\text { Akhir }\left(\mathbf{W}_{3}\right) \\
(\mathrm{gr})\end{array}$ & $\begin{array}{c}\text { Kadar Zat } \\
\text { Terbang } \\
(\%)\end{array}$ \\
\hline 0,5 & 63,01 & 64,21 & 63,95 & 21,66 \\
\hline 1 & 59,13 & 60,33 & 60,08 & 20,83 \\
\hline 1,5 & 54,49 & 55,69 & 55,43 & 21,66 \\
\hline 2 & 56,68 & 57,88 & 57,64 & 20 \\
\hline 2,5 & 60,52 & 61,72 & 61,48 & 20 \\
\hline 3 & 54,11 & 55,31 & 55,06 & 20,83 \\
\hline
\end{tabular}

Menurut persyaratan kualitas karbon aktif Standar Nasional Indonesia (SNI) 06-3730-1995, kadar zat terbang maksimal yang terkandung dalam karbon aktif yang baik adalah 25\%. Berdasarkan tabel 4.3 dapat dilihat bahwa hasil analisa kadar zat terbang yang di peroleh berkisar antara 20 $21,66 \%$. Maka hasil analisa kadar zat terbang pada penelitan ini telah memenuhi Standar Nasional Indonesia (SNI) 063730-1995, yakni kurang dari 25\%.
Kadar volatil atau zat terbang merupakan kandungan senyawa yang mudah menguap selain air pada arang aktif (Pari, 2000). Kadar zat terbang merupakan hasil dekomposisi zat-zat penyusun arang akibat proses pemanasan selama pengarangan dan bukan komponen penyusun arang. Kadar zat teruap (terbang) pada karbon merupakan banyaknya zat yang menguap dari suatu bahan, yang menguap terdiri atas gas-gas yang mudah terbakar, seperti hidrogen dan karbon monoksida serta sebagian kecil uap yang dapat mengembun (Meilianti, 
2017). Berdasarkan tabel 4.3 hasil analisa kadar zat terbang karbon aktif dapat diambil hubungan antara \% kadar zat terbang dengan konsentrasi $\mathrm{HCl}$ yang disajikan pada gambar 3.

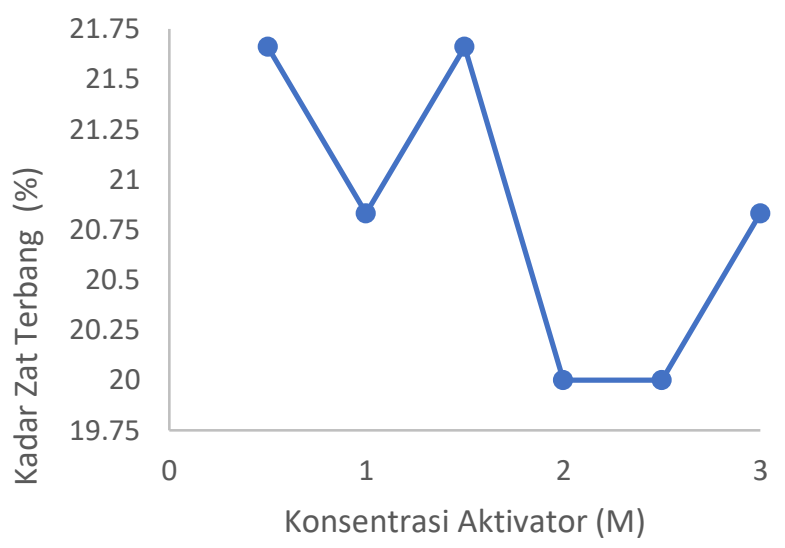

Gambar 3. Grafik Pengaruh Konsentrasi HCl Terhadap Kadar Zat Terbang

Dari Gambar 3 di atas menunjukkan bahwa konsentrasi bahan aktivator tidak menyebabkan kenaikan kadar zat terbang atau sebaliknya, tetapi menghasilkan karbon aktif dengan nilai kadar zat terbang yang fluktuatif. Kadar zat menguap (terbang) akan menurun seiring dengan meningkatnya suhu karbonisasi dan suhu aktivasi, hal ini disebabkan ketidaksempurnaan penguraian senyawa non karbon selama proses aktivasi. Dalam hal ini dapat disimpulkan bahwa kenaikan konsentrasi bahan aktivator tidak begitu mempengaruhi kadar zat terbang.

Menurut Rahim dan Indriyani (2010), Besarnya kadar zat menguap ditentukan oleh waktu dan suhu pengarangan. Ketika lama proses karbonisasi dan suhu ditingkatkan maka zat menguap yang terbuang akan semakin banyak, sehingga akan diperoleh nilai kadar zat menguap yang semakin rendah. Meningkatnya suhu karbonisasi akan menguapkan senyawa volatile yang masih tertinggal terutama ter, hal ini akan menyebabkan jumlah pori yang terbentuk bertambah banyak. Karbon dengan kondisi tersebut mungkin dapat dijadikan sebagai karbon aktif dengan permukaan yang tidak lagi ditutupi oleh senyawa polar sehingga memiliki kemampuan menyerap (Pari, 2004).

Hasil kadar zat terbang pada penelitian ini lebih rendah dibandingkan karbon aktif yang diaktivasi dengan larutan $\mathrm{H}_{3} \mathrm{PO}_{4}$ dan $\mathrm{NH}_{4} \mathrm{HCO}_{3}$ dengan temperatur karbonisasi $600^{\circ} \mathrm{C}$, yaitu antara 39,1 - 45\% (Ghafarunnisa, dkk 2017). Hal ini disebabkan temperatur karbonisasi pada penelitian ini lebih tinggi, yaitu sebesar $700^{\circ} \mathrm{C}$ sehingga zat-zat volatil yang terdapat pada karbon aktif berkurang. Selain itu proses aktivasi kimia juga bisa menambah volatile matter karena proses pencucian setelah aktivasi kimia yang kurang sempurna.

\section{Uji Kadar Karbon Terikat}

Pengujian kadar zat karbon terikat merupakan salah satu parameter yang harus di uji untuk mengetahui kualitas dari karbon aktif. Karbon dalam arang aktif adalah hasil dari proses pengarangan/karbonisasi selain abu (zat anorganik) dan zat terbang (zat-zat atsiri yang masih terdapat pada pori pori arang) (Achmad, 2011). Definisi ini hanya berupa pendekatan (SNI 1995). Penetapan kadar karbon terikat bertujuan untuk mengetahui kandungan karbon setelah proses karbonisasi dan aktivasi. Pengukuran kadar karbon terikat dihitung dengan menggunakan rumus :

Kadar Karbon Terikat $(\%)=100 \%-($ Kadar Zat Menguap + Kadar Abu)\%

(6)

Data hasil uji kadar karbon terikat ditunjukan pada tabel 4.

Tabel 4. Data Hasil Pengamatan Analisa Kadar Karbon Terikat

\begin{tabular}{cccc}
\hline Konsentrasi Aktivator $(\mathbf{M})$ & Kadar Abu (\%) & Kadar Zat Terbang (\%) & Kadar Karbon Terikat $(\%)$ \\
\hline 0,5 & 8,33 & 21,66 & 70 \\
1 & 7,5 & 20,83 & 71,66 \\
1,5 & 7,5 & 21,66 & 70,83 \\
2 & 6,66 & 20 & 73,33 \\
2,5 & 7,5 & 20 & 72,5 \\
3 & 6,66 & 20,83 & 72,5 \\
\hline
\end{tabular}

Menurut persyaratan kualitas karbon aktif Standar Nasional Indonesia (SNI) 06-3730-1995, kadar karbon terikat minimal yang terkandung dalam karbon aktif yang baik adalah 65\%. Berdasarkan tabel 4.4 dapat dilihat bahwa hasil analisa kadar karbon terikat yang di peroleh berkisar antara 70 $73,33 \%$. Maka hasil analisa kadar zat terbang pada penelitan ini telah memenuhi Standar Nasional Indonesia (SNI) 063730-1995, yakni lebih tinggi dari 65\%.. Berdasarkan tabel 4.4 hasil analisa kadar karbon terikat karbon aktif dapat diambil hubungan antara \% kadar karbon terikat dengan konsentrasi $\mathrm{HCl}$ yang disajikan pada gambar 4 .

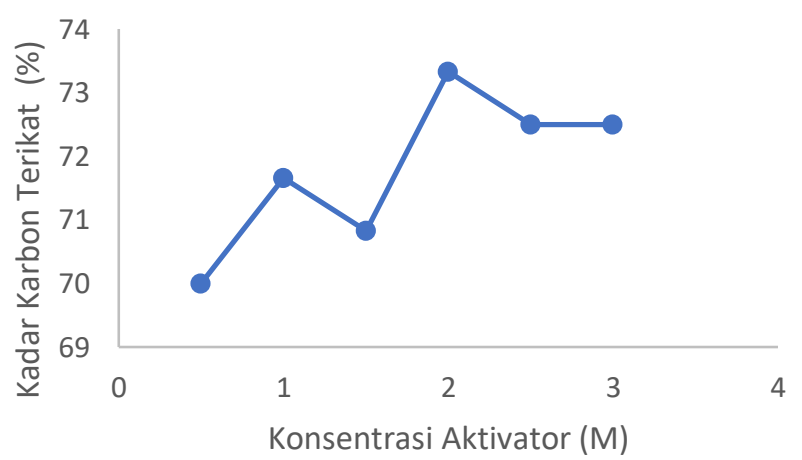

Gambar 4. Grafik Pengaruh Konsentrasi HCl Terhadap Kadar karbon terikat 
Dari gambar 4, menunjukkan bahwa konsentrasi bahan aktivator tidak menyebabkan kenaikan kadar zat terbang atau sebaliknya, tetapi menghasilkan karbon aktif dengan nilai kadar zat terbang yang fluktuatif. Besarnya kadar karbon terikat dipengaruhi oleh kadar abu dan kadar zat terbang (Pari, 2004). Karena kadar karbon terikat ditetapkan dengan jalan pengurangan dari $100 \%$ - (kadar abu + zat terbang). Dalam hal ini dapat disimpulkan bahwa perbedaan konsentrasi bahan aktivator tidak begitu mempengaruhi kadar karbon terikat karbon aktif yang dihasilkan.

Kadar karbon terikat karbon aktif sangat dipengaruhi oleh jenis bahan baku, karena kadar abu dan kadar zat terbang karbon aktif untuk setiap bahan baku berbeda-beda (Hartoyo, 1974). Semakin tinggi kadar abu dan atau zat terbang, semakin rendah kadar karbon terikat. Besar kecilnya kadar karbon terikat yang dihasilkan, selain dipengaruhi oleh tinggi rendahnya kadar zat menguap dan kadar abu juga dipengaruhi oleh kandungan selulosa dan lignin bahan yang dapat dikonversi menjadi atom karbon (Pari, 2004). Semakin rendahnya kadar karbon menunjukkan banyak atom karbon yang bereaksi dengan uap air menghasilkan gas $\mathrm{CO}$ dan $\mathrm{CO}_{2}$.

Hasil kadar karbon terikat pada penelitian ini lebih tinggi dibandingkan karbon aktif yang diaktivasi dengan larutan $\mathrm{H}_{3} \mathrm{PO}_{4}$ dan $\mathrm{NH}_{4} \mathrm{HCO}_{3}$ dengan temperatur karbonisasi $600^{\circ} \mathrm{C}$, yaitu antara 40,2 - 46,5\% (Ghafarunnisa, dkk 2017). Hal ini disebabkan temperatur karbonisasi pada penelitian ini lebih tinggi, yaitu sebesar $700^{\circ} \mathrm{C}$ Sehingga cukup optimal menghilangkan zat menguap (volatil) pada karbon aktif. Semakin rendah zat volatil pada karbon aktif, maka semakin tinggi kadar karbon terikat yang dihasilkan.

\section{Uji Daya Serap Larutan Iodin}

Pengujian daya serap larutan iodin merupakan salah satu parameter yang harus di uji untuk mengetahui kualitas dari karbon aktif. Penentuan daya serap iodin bertujuan untuk menentukan kapasitas adsorpsi arang aktif (Jankowska, dkk. 1991). Parameter yang dapat menunjukan kualitas arang aktif adalah daya adsorpsi terhadap larutan iodin. Semakin besar bilangan iodnya maka semakin besar kemampuan dalam mengadsopsi adsorbat atau zat terlarut. Oleh karena itu, daya serap terhadap iodium merupakan parameter yang sangat penting dalam menilai kualitas karbon aktif.

Pengujian daya serap iodin merupakan faktor utama untuk menentukan arang aktif terbaik yang akan digunakan sebagai adsorben pada penelitian selanjutnya. Sampel kering sebanyak $\pm 0,25 \mathrm{~g}$ dimasukkan kedalam labu erlenmeyer yang dibungkus aluminium foil, ditambahkan $25 \mathrm{ml}$ larutan Iodin $0,1 \mathrm{~N}$, kemudian dikocok selama 15 menit pada suhu kamar lalu disaring. Filtrat sebanyak $10 \mathrm{ml}$ dititrasi dengan larutan $\mathrm{Na}_{2} \mathrm{~S}_{2} \mathrm{O}_{3} .5 \mathrm{H}_{2} \mathrm{O} 0,1 \mathrm{~N}$ hingga berwarna kuning muda lalu diberi beberapa tetes indikator amilum $1 \%$ dan titrasi dilanjutkan sampai warna biru tepat hilang. Data hasil uji daya serap larutan iodin ditunjukan pada tabel 5 .

Tabel 5. Data Hasil Pengamatan Analisa Daya Serap larutan iodin

\begin{tabular}{ccc}
\hline Konsentrasi Aktivator $(\mathbf{M})$ & Volume Titran $\mathbf{N a}_{2} \mathbf{S}_{\mathbf{2}} \mathbf{O}_{\mathbf{3}}(\mathbf{m l})$ & Daya Serap Terhadap Larutan Iodin $(\mathbf{m g} / \mathbf{g})$ \\
\hline 0,5 & 10,9 & $1.205,65$ \\
1 & 8 & $1.573,68$ \\
1,5 & 7,5 & $1.637,13$ \\
2 & 7 & $1.700,59$ \\
2,5 & 6,4 & $1.776,74$ \\
3 & 6 & $1.827,50$ \\
\hline
\end{tabular}

Menurut persyaratan kualitas karbon aktif Standar Nasional Indonesia (SNI) 06-3730-1995, daya serap larutan iodin minimal yang dihasilkan dalam karbon aktif yang baik adalah $750 \mathrm{mg} / \mathrm{g}$. Berdasarkan tabel 4.5 dapat dilihat bahwa hasil analisa daya serap larutan iodin yang di peroleh berkisar antara 1.205,65 - 1.827,50 mg/g. Maka hasil analisa daya serap larutan iodin pada penelitan ini sangat bagus dan telah memenuhi Standar Nasional Indonesia (SNI) 06-3730-1995, yakni lebih tinggi dari $750 \mathrm{mg} / \mathrm{g}$. Daya serap larutan iodin tertinggi dimiliki oleh karbon aktif yang diaktivasi dengan asam klorida $(\mathrm{HCl})$ pada konsentrasi $3 \mathrm{M}$ dengan suhu karbonisasi $700^{\circ} \mathrm{C}$ yakni sebesar $1.827,50 \mathrm{mg} / \mathrm{g}$. Sedangkan untuk daya serap larutan iodin terendah dimiliki oleh karbon aktif yang diaktivasi dengan asam klorida $(\mathrm{HCl})$ pada konsentrasi $0,5 \mathrm{M}$ dengan suhu karbonisasi $700^{\circ} \mathrm{C}$ yakni sebesar $1.205,65 \mathrm{mg} / \mathrm{g}$.

Daya serap iodin ini dipengaruhi oleh proses analisa yang dilakukan dari awal, terutama saat proses titrasi yang menggunakan larutan iodin. Larutan iodin sangat sensitif terhadap cahaya, sehingga harus diletakkan di wadah gelap ataupun digunakan dalam ruangan yang gelap pula (Ghafarunnisa, dkk 2017). Daya serap terhadap larutan iodin menunjukkan kemampuan arang aktif menyerap zat dengan ukuran molekul yang lebih kecil dari $10 \dot{\mathrm{A}}$ atau memberikan indikasi jumlah pori yang berdiameter $10-15 \dot{A}$. Semakin tinggi daya serap iodium maka semakin baik kualitas arang aktif (Rumidatul, 2006). Berdasarkan tabel 4.5 hasil analisa daya serap laritan iodin karbon aktif dapat diambil hubungan antara daya serap iodin $(\mathrm{mg} / \mathrm{g})$ dengan konsentrasi $\mathrm{HCl}$ yang disajikan pada gambar 5 .

Dari gambar 5, terlihat bahwa semakin tinggi konsentrasi asam klorida yang digunakan pada saat aktivasi maka daya serap yang dihasilkan karbon aktif akan meningkat. Hal ini disebabkan semakin tinggi konsentrasi asam klorida maka pori-pori dari karbon aktif semakin besar sehingga daya serap yang dihasilkan juga semakin besar. Bilangan iodin yang diperoleh relatif tinggi yang berarti karbon aktif memiliki daya serap yang cukup baik, selain itu telah memenuhi standar SNI dimana minimal bilangan iodin yang dihasilkan sebesar 750 $\mathrm{mg} / \mathrm{g}$. Peningkatan daya serap ini memperlihatkan bahwa atom karbon yang membentuk kristalit heksagonal makin banyak sehingga celah atau pori yang terbentuk di antara lapisan kristalit juga makin besar (Ghafarunnisa, dkk 2017). 


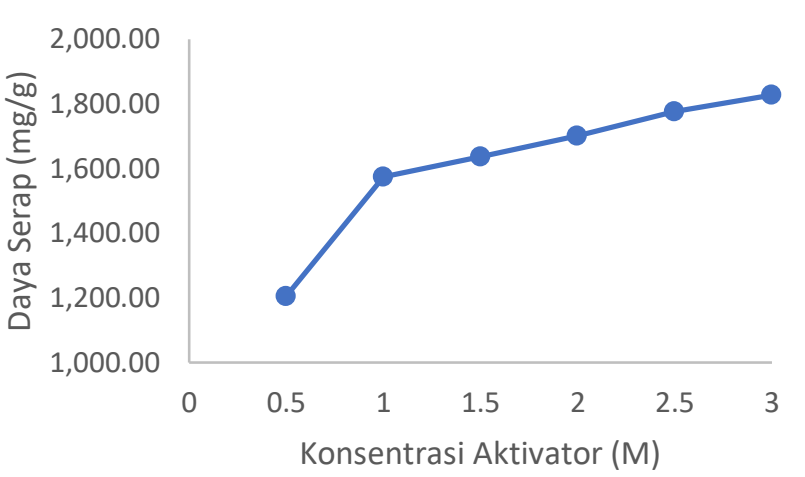

Gambar 5. Grafik Pengaruh Konsentrasi HCl Terhadap Daya Serap Iodin

Penambahan aktivator memberikan pengaruh yang kuat untuk mengikat senyawa-senyawa tar keluar melewati poripori dari karbon aktif sehingga permukaan dari karbon aktif tersebut semakin lebar atau luas yang menyebabkan semakin besar pula daya serap karbon aktifnya (Suhendarwati, dkk. 2012). Selain itu semakin tinggi konsentrasi aktivator juga menghasilkan struktur mesopori yang mempunyai luas permukaan dan volume pori yang besar (Baquero dkk., 2003). Hal ini dapat disimpulkan bahwa perbedaan konsentrasi aktivator sangat berpengaruh terhadap daya serap iodinnya, yakni semakin meningkat konsentrasi aktivatornya semakin meningkat pula daya serap iodinnya.

Hasil daya serap larutan iodin pada penelitian ini lebih baik yakni lebih tinggi dibandingkan karbon aktif yang diaktivasi dengan larutan $\mathrm{H}_{3} \mathrm{PO}_{4}$ dan $\mathrm{NH}_{4} \mathrm{HCO}_{3}$ dengan konsentrasi aktivator 1, 1,5, 2, 2,5 $\mathrm{M}$ dan temperatur karbonisasi $600^{\circ} \mathrm{C}$, yaitu berkisar $1172,556-1177,632 \mathrm{mg} / \mathrm{g}$ (Ghafarunnisa, dkk 2017). Hal ini disebabkan konsentrasi dan temperatur karbonisasi pada penelitian ini lebih tinggi, yaitu sebesar $700^{\circ} \mathrm{C}$ dan jenis aktivator yang berbeda. Daya serap iodin karbon aktif dari hasil penelitian ini juga lebih baik dibandingkan dengan karbon aktif yang diproduksi dengan aktivasi secara kimia dan fisika dengan aliran gas nitrogen, yang hanya mencapai bilangan iodin maksimal $500 \mathrm{mg} / \mathrm{g}$ (Pitumila, 2014). Daya serap iodin hasil penelitian ini juga lebih baik dari bilangan iodin karbon aktif dari batubara sub bituminus yang diaktivasi termal pada temperatur $900^{\circ} \mathrm{C}$ yakni 493 mg/g (Ramadhan dkk., 2016).

\section{Analisa Scanning Electron Microscope (SEM)}

Analisis struktur permukaan pori-pori pada karbon aktif dari batubara jenis lignit dapat dilakukan menggunakan scanning electron microscope (SEM). Analisis ini bertujuan untuk mengetahui morfologi permukaan karbon aktif akibat proses karbonisasi dan aktivasi. Pada prinsipnya analisis permukaan melibatkan radiasi permukaan dengan sumber energi yang cukup untuk menembus dan menimbulkan emisi dari permukaan berkas energi yang bisa dianalisis. Analisis morfologi permukaan dilakukan pada karbon aktif sebelum aktivasi dan setelah aktivasi dengan larutan $\mathrm{HCl} 3 \mathrm{M}$. Hal ini dikarenakan pada hasil uji kualitas karbon aktif menurut Standar Nasional Indonesia (SNI) 06-3730-1995 dengan macam-macam konsentrasi aktivatornya, menunjukan hasil uji yang paling baik yakni pada konsentrasi $3 \mathrm{M}$. Berikut hasil analisa SEM sebelum aktivasi dan sesudah aktivasi pada gambar 6 dan 7

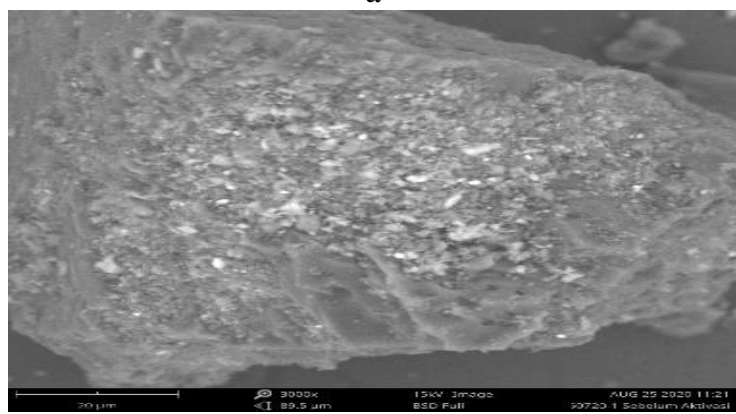

b

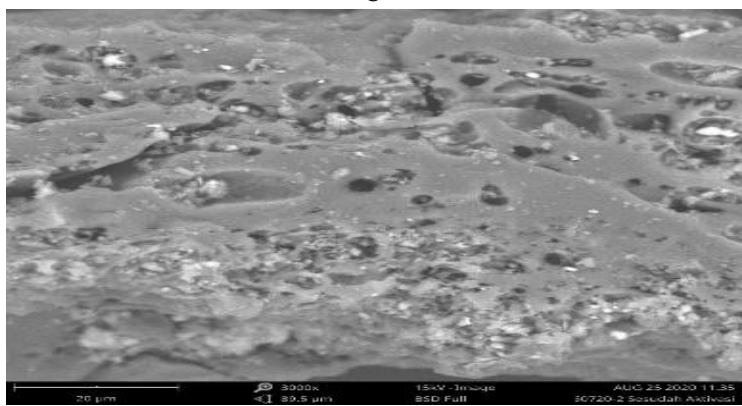

Gambar 6. Hasil SEM Sebelum Aktivasi (a) dan Sesudah Aktivasi (b) dengan perbesaran 3000x

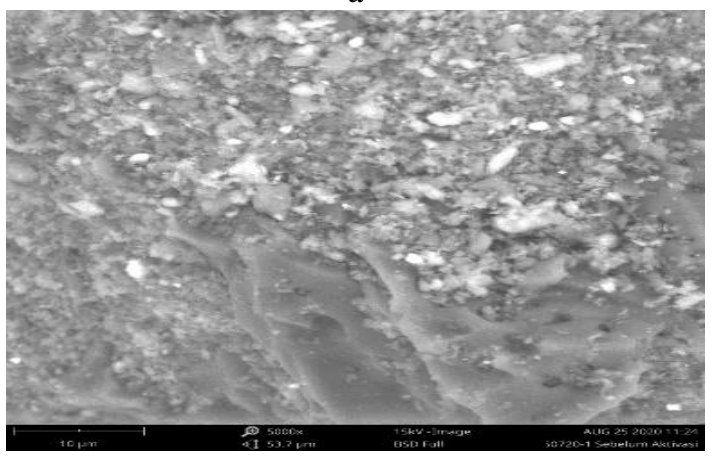

b

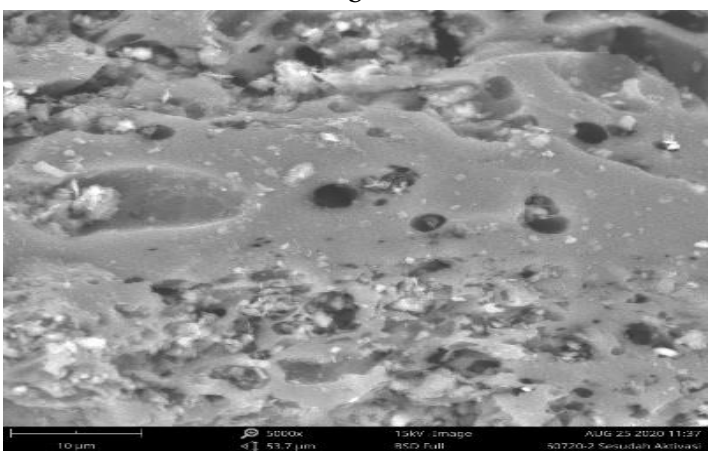

Gambar 7. Hasil SEM Sebelum Aktivasi (a) dan Sesudah Aktivasi (b) dengan perbesaran 5000x

Hasil analisa SEM pada gambar 6 dan 7 adanya perubahan dari struktur arang menjadi arang aktif. Terdapat perbedaan struktur pori karbon aktif sebelum aktivasi (a) dengan karbon aktif setelah aktivasi menggunakan aktivator $\mathrm{HCl} 3 \mathrm{M}$. Pada karbon aktif teraktivasi $\mathrm{HCl} 3 \mathrm{M}$ pori-pori yang terbentuk lebih banyak dan membentuk rongga-rongga 
pori-pori dengan kedalaman yang lebih besar bila dibandingkan dengan karbon aktif sebelum aktivasi. Ini mengindikasikan bahwa aktivasi dapat menambah besaran pori dan membentuk pori baru, sehingga memiliki kemampuan untuk menyerap molekul yang ukurannya jelaskan lebih makropori. Hal ini disebabkan karena pada karbon aktif teraktivasi $\mathrm{HCl} 3 \mathrm{M}$ melalui proses karbonisasi dan aktivasi kimia dengan menggunakan larutan $\mathrm{HCl}$ sedangkan pada karbon aktif sebelum aktivasi hanya melalui proses karbonisasi.

Menurut Chen-hao dkk. (2016) distribusi mesopori dan mikropori dapat meningkatkan nilai kapasitansi. Permukaan kedua karbon aktif berbentuk lubang-lubang yang didapatkan selama aktivasi berguna untuk adsorpsi ion dan menyimpan muatan. Hal ini menunjukkan selama proses aktivasi, pelatpelat karbon kristalit yang tidak teratur mengalami pergeseran sehingga permukaan kristalit menjadi terbuka terhadap gas pengaktif yang dapat mendorong residu-residu hidrokarbon. Pergeseran pelat karbon menghasilkan pori yang baru dan mengembangkan mikropori awal menjadi makropori, serta menurunkan derajat kristalinitas (Malik dan Riad, 2013).

Pembentukan dan pembesaran pori disebabkan oleh penguapan komponen selulosa yang terdegradasi dan lepasnya zat mudah menguap. Pengurangan senyawa hidrokarbon menghasilkan permukaan karbon aktif terlihat semakin jelas. Proses aktivasi bertujuan untuk memperbesar pori yaitu dengan cara memecahkan ikatan hidrokarbon atau mengoksidasi molekul-molekul permukaan sehingga karbon mengalami perubahan yaitu luas permukaannya bertambah besar dan berpengaruh terhadap daya adsorpsi.

\section{Kesimpulan}

Berdasarkan tujuan dan hasil penelitian yang di peroleh dapat disimpulkan bahwa :

1. Kualitas karbon aktif yang diperoleh dari penelitian ini dengan nilai kadar air berkisar antara 5,83-9,16\%, kadar abu berkisar antara 6,66-8,33\%, kadar zat terbang berkisar antara $20-21,66 \%$, kadar karbon terikat berkisar antara $70-$ $73,33 \%$ dan daya serap iodin berkisar antara 1.205,65 $1.827,50 \mathrm{mg} / \mathrm{g}$. Dengan demikian kualitas karbon aktif dari batubara jenis lignit yang dihasilkan telah memenuhi standar dari karbon aktif yang sesuai SNI 06-3730-1995.

2. Pengaruh variasi konsentrasi aktivator tidak begitu berpengaruh terhadap kualitas karbon aktif untuk nilai kadar abu, kadar zat terbang dan kadar karbon terikat, tetapi menghasilkan karbon aktif dengan nilai yang fluktuatif. Sedangkan variasi konsentrasi aktivator sangat berpengaruh terhadap kualitas karbon aktif untuk nilai kadar air dan daya serap iodin. Semakin tinggi konsentrasi aktivator maka kadar air dalam karbon aktif semakin berkurang. Dan semakin tinggi konsentrasi aktivator maka semakin meningkat daya serap iodinnya.

3. Hasil SEM menunjukkan bahwa morfologi karbon aktif dari batubara jenis lignit yang di aktivasi dengan $\mathrm{HCl}$ pada konsentrasi $3 \mathrm{M}$ memiliki pori-pori yang terbentuk lebih banyak dan membentuk pori-pori dengan kedalaman yang lebih besar dibandingkan dengan karbon aktif sebelum aktivasi.

\section{Daftar Pustaka}

Abdullah, Mikrajuddin, dan Khairurrijal. 2008. Karakterisasi Nanomaterial. A Review: Jurnal Nanoscience dan Teknologi. Vol. 2, No.1.

Arsad dan Hamdi, 2010. Teknologi Pengolahan Dan Pemanfaatan Karbon Aktif Untuk Industri. Jurnal Riset Industri Hasil Hutan Vol.2, No.2, hal 43-51.

Aziz, A.A., Mary, S., dan Achmad, Z., 2013. Efektivitas Arang Aktif Dalam Mengadsorpsi Logam Cd Dan Pb Dalam Air Limbah Industri. Makassar: Universitas Hasanudin.

Badan Standarisasi Nasional [BSN], 1995. Arang Aktif Teknis (SNI) 06-3730- 1995. Jakarta: Standar Nasional Indonesia.

Baquero, M.C., Giraldo, L., Moreno, J.C., Garcia, F.S., Alonso, A.M., and Tascon, J.M.D., (2003), Activated Carbon by Pyrolysis of Coffee Bean Husks in Presence of Phosphoric Acid, Journal of Analytical and Applied Pyrolysis, 70, pp. 779-784.

Budiono, A; Suhartana; dan Gunawan. 2009. Pengaruh Aktivasi Arang Tempurung Kelapa Dengan Asam Sulfat dan Asam Posfat untuk Adsorpsi

Dewi, T.K., Arif, N., dan Edwin, P., 2009. Pembuatan Karbon Aktif Dari Kuli Ubi Kayu (Mannihot Esculenta). Jurnal Teknik Kimia, No. 1, Vol. 16, hal 24-30

Eliabeth, (2006), Experiment on The Generation of Activated Carbon from Biomass, Institute for Nuclear and Energy Technologies Forschungs karlsruhe, Germany, pp. 106 - 111.

Erlina, Umiatin, dan Esmar, B., 2015. Pengaruh Konsentrasi Larutan Koh Pada Karbon Aktif Tempurung

Kelapa Untuk Adsorpsi Logam Cu. Prosiding Seminar Nasional Fisika (E-Journal), Jakarta: Jurusan Fisika, Fakultas MIPA, Universitas Negeri Jakarta.

Esterlita, M.O. dan Herlina, N., (2015), Pengaruh Penambahan Aktivator $\mathrm{ZnCl}_{2}, \quad \mathrm{KOH}, \quad$ dan $\mathrm{H}_{3} \mathrm{PO}_{4}$ dalam Pembuatan Karbon Aktif dari Pelepah Aren (Arenga Pinnata), Jurnal Teknik Kimia USU, 4(1), hal. 1-6.

Ghafarunnisa, D., Abdul, R., dan Bantar, T.S.R., 2017. Pemanfaatan Batubara Menjadi Karbon Aktif Dengan Proses Karbonisasi Dan Aktivasi Menggunakan Reagen Asam Fosfat $\left(\mathrm{H}_{3} \mathrm{PO}_{4}\right)$ Dan Ammonium Bikarbonat $\left(\mathrm{Nh}_{4} \mathrm{HCO}_{3}\right)$. Yogyakarta: Teknik Pertambangan, UPN Veteran.

Guo, Z., Zhang, A., Zhang, J., Liua, H., Kang, Y., and Zhang, C., (2017), An Ammoniation-Activation Method to Prepare Activated Carbon with Enhanced Porosity and Functionality, Powder Technology, 309, pp. 74- 78.

Hartanto, S. dan Ratnawati. 2010. Pembuatan Karbon Aktif dari Tempurung Kelapa Sawit dan Metode Aktivasi Kimia. Jurnal Sains Materi Indonesia, Vol. 12, No. 1.

Hartoyo. 1974. Arang Aktif: Pembuatan dan Kegunaan. Jakarta: Dephut.

Hendra, D. 2006. Pembuatan Arang Aktif dari Tempurung Kelapa Sawit dan Serbuk Kayu Gergajian Campuran. Pusat Penelitian dan Pengembangan Hasil Hutan Bogor. Jurnal Penelitian Hasil Hutan. Vol. 24, No. 2.

Jankowska, H., A. Swiatkowski, dan J. Choma, 1991, Active Carbon, Horwood, London 
Kartika, V. 2016. Pengaruh variasi suhu karbonisasi terhadap mikrostruktur dan derajat kristalinitas karbon aktif kulit singkong sebagai bahan dasar GDL. Pillar of Physics. Vol. 7 No.1.

Kroschwitz, J. T. 1990. Polimer Characterization and Analysis. John Wiley \& Sons, Inc. New York.

Kusdarini, E., Agus, B., dan Desyana, G., 2017. Produksi Karbon Aktif dari Batubara Bituminus dengan Aktivasi Tunggal $\mathrm{H}_{3} \mathrm{PO}_{4}, \quad$ Kombinasi $\mathrm{H}_{3} \mathrm{PO}_{4}$ $\mathrm{NH}_{4} \mathrm{HCO}_{3}$, dan Termal. Reaktor, Vol. 17 No. 2, Hal. 74-80.

Kusmiyati, Lystanto, P.A., Pratiwi, K., 2012. Pemanfaatan Karbon Aktif Arang Batubara (KAAB) untuk Menurunkan Kadar Ion Logam Berat Cu2+ dan Ag+ pada Limbah Cair Industri, Reaktor, 14(1), pp. 51-60.

Kvech, Steve, and T. Erika. 1998. Activated Carbon. Departement of Civil and. Environmental Engineering. Virginia Tech University. United States of America.

Martin, A. 2008. Farmasi Fisika Dasar-Dasar Farmasi Fisik dalam Ilmu Farmasetik Edisi Ketiga jilid 2. Jakarta: UI Press.

Lu, W. and Chung, D.D.L. 2001. Preparation of conductive carbons with high surface area. Carbon 39: 39-44.

Malik, U. dan Riad, S. 2013. Pengaruh Lama Aktivasi Terhadap Komposisi dan Struktur Kimia dan Mutu Arang Aktif Serbuk Gergaji Jelutung. Riau: Jurusan Fisika FMIPA Universitas Riau.

Marsh, H. and R. R. Francisco. 2006. Activated Carbon. Ukraina: Elsivier Science and Technology Books.

Martin, A. 2008. Farmasi Fisika Dasar-Dasar Farmasi Fisik dalam Ilmu Farmasetik Edisi Ketiga jilid 2. Jakarta: UI Press.

Meilianti, 2017. Karakteristik Karbon Aktif Dari Cangkang Buah Karet Menggunakan Aktivator $\mathrm{H}_{3} \mathrm{PO}_{4}$. Distilasi, Vol. 2 No. 2, Hal. 1-9.

Mentari., V.A., Gewa., H., Seri., M., 2018. Perbandingan Gugus Fungsi Dan Morfologi Permukaan Karbon Aktif Dari Pelepah Kelapa Sawit Menggunakan Aktivator Asam Fosfat (H3po4) Dan Asam Nitrat $\left(\mathrm{HNO}_{3}\right)$. Jurnal Teknik Kimia USU, Vol. 7, No. 1

Pari, G., (1996), Pembuatan Arang Aktif dari Serbuk Gergajian Sengon dengan Cara Kimia, Buletin Penelitian Hasil Hutan, 14(8), pp. 308-320.

Pari, G. 2000. Pembuatan Arang Aktif Dari Batubara. Buletin Penelitian Hasil Hutan Vol. 17 No.4 : 220 - 230.

Pari, G., (2004), Kajian Struktur Arang Aktif dari Serbuk Gergaji Kayu sebagai Adsorben Emisi Formaldehida Kayu Lapis, disertasi, Institut Pertanian Bogor.

Pitumila, J., (2014). Pembuatan Karbon Aktif dari Batubara, Promine, 1(1), hal. 1-12.

Pitulima, 2018. Studi Daya Serap Karbon Aktif Batubara Terhadap Penurunan Kadar Logam Cu Dalam Larutan $\mathrm{CuSO}_{4}$. Bangka: Jurusan Teknik Pertambangan, Universitas Bangka Belitung.

Priyono, A. 1989. Peranan batubara menjelang tinggal landas dalam Pelita VI. Jakarta: Presiding Lokakarya Energi.

Rahim, M. dan Indriyani, O.S., (2010), Pembuatan Karbon Aktif dari Batubara Peringkat Rendah, Jurnal Teknologi Media Perspektif, 10(2), hal. 60-114.

Ramadhan, R.B., Solihin, S., dan Pulungan, L., (2016), Kajian Pembuatan Karbon Aktif Batubara SubBituminus (Coalite) dari PT Bukit Asam
(Persero) Tbk untuk Memenuhi Spesifikasi Ekstraksi Logam Emas, Prosiding Teknik Pertambangan, 2(1), hal. 105-112.

Ridhuan, K., Dan Joko, S., 2016. Perbandingan Pembakaran Pirolisis Dan Karbonisasi Pada Biomassa Kulit Durian Terhadap Nilai Kalori. Jurnal Teknik Mesin Univ. Muhammadiyah Metro, Turbo Vol. 5 No. 1.

Riza, A., Yazid, B., Herri, S., dan Dwiwahdju, S., 2017. Pengaruh Kadar Karbon Pada Proses Gasifikasi. Jurusan Teknik Mesin, Fakultas Teknik, Universitas Tarumanagara. Sinergi, Vol. 21, No. 1, Hal. 1-8.

Saisa, K., dan Kartika, Z., 2019. Pengaruh Karbon Aktif Batubara Sub bituminus Diaktivasi Menggunakan $\mathrm{HNO}_{3}$ Dan $\mathrm{C}_{6} \mathrm{H}_{8} \mathrm{O}_{7}$. Jurnal Ilmiah Teknik Kimia UNPAM, Vol. 3 No. 1.

Sandi., S.P., dan Astuti, 2014. Pengaruh Waktu Aktivasi Menggunakan H3po4 Terhadap Struktur Dan Ukuran Pori Karbon Berbasis Arang Tempurung Kemiri. Jurnal Fisika Unand Vol. 3, No. 2.

Speight, J. G., 2005. Handbook of Coal Analysis. Wiley Interscienc, Hoboken, New Jersey.

Su, Hui., Zhibin, Ye., Nuri, Hmidic., and Ramesh Subramaniana. 2017. Carbon Nanosphere-Iron Oxide Nanocomposites As High-Capacity Adsorbents For Arsenic Removal. Royal Society of Chemistry Advances.

Tanaka, K. Aoki, H. Ago, H. Yamake, T. and Okahara, K. 1997. Interlayer Interaction Of Two Graphene Sheets As A Model Of Double Layer Carbon Nanotubes

Wijaya, H. 2018. Pembuatan Dan Karakterisasi Karbon Aktif Dari Limbah Kulit Singkong (Manihot Utilissima) Dengan Aktivator Zncl2 Dan Nacl Untuk Mengadsorpsi Senyawa Fenantrena (Skripsi). Jurusan Kimia. Universitas Lampung.

Yola, 2013. Pemanfaatan Arang Aktif Sebagai Absorban Logam Berat Dalam Air Lindi Di Tpa Pakusari Jember. Jember: Jurusan Kimia, Fakultas Matematika Dan Ilmu Pengetahuan Alam, Universitas Jember.

Zakaria, 2003. Analisis Kandungan Mineral Magnetik pada Batuan Beku dari Daerah Istimewa Yogyakarta dengan Metode X-Ray Diffiaction, skripsi, Fakultas Keguruan dan Ilmu Pendidikan, Universitas Haluoleo : Kendari.

Zhang, C. C. 2007. Fundamentals of Environmental Sampling and Analysis. John Wiley \& Sons, Inc. New Jersey. 